\title{
The evaluation of the relationship of clinical and laboratory evidence with renal damage in the pediatric patients that had urinary tract infections
}

\author{
Idrar yolu enfeksiyonu geçiren çocuk hastalarda klinik ve laboratuvar kanıtların böbrek \\ hasarı ile ilişkisinin değerlendirilmesi
}

Selcuk Yuksel, Tulay Becerir, Burcin Seyhan

Gönderilme tarihi:03.09.2021

Kabul tarihi:20.09.2021

\begin{abstract}
Purpose: Urinary tract infection (UTI) is one of the important infectious diseases of childhood age. It causes serious late-term complications by leading to development of renal scarring in some pediatric patients. In the present study, it was aimed to determine the risk factors in development of renal damage in the pediatric patients that admitted with clinical of acute pyelonephritis.

Materials and methods: In our study, the medical files of the patients were admitted to the pediatric nephrology polyclinic of Pamukkale University Medical Faculty and followed-up with the diagnosis of urinary tract infection were retrospectively evaluated. The study included 197 patients diagnosed with acute pyelonephritis (confirmed by urine culture and clinical evidence) and undergoing dimercaptosuccinic acid (DMSA) scintigraphic imaging. The clinical evidence (fever, recurrent UTI, voiding dysfunction etc.), laboratory evidence (C-reactive protein (CRP) and erythrocyte sedimentation rate (ESR), white blood cell (WBC) count, polymorphonuclear leukocyte (PNL) count, mean platelet volume (MPV), platelet count, serum urea and creatinine levels) and imaging evidence (urinary tract system ultrasonography (USG), voiding cystourethrography (VCUG) and DMSA scintigraphy) of the patients detected at admission and obtained by anamnesis were evaluated.

Results: The number of the female patients $(n=153)$ was found significantly higher than number of the male patients $(n=44)(p<0.001)$. It was detected that pretreatment fever of $38^{\circ} \mathrm{C}$ and over, persisting clinical evidence for 2 days or longer, the presence of recurrent UTI and high levels of WBC, PNL, ESR and CRP significantly increased renal damage in the patients $(p<0.001)$. It was determined that USG and VCUG have low sensitivity regarding prediction of renal damage.

Conclusion: Determination of renal damage rate by clinical and laboratory data detected at patient admission may contribute to a reduction in morbidity and mortality rates by applying an appropriate follow-up and treatment modality.
\end{abstract}

Key words: Urinary tract infection, child, risk factors, renal scar, fever.

Yuksel S, Becerir T, Seyhan B. The evaluation of the relationship of clinical and laboratory evidence with renal damage in the pediatric patients that had urinary tract infections. Pam Med J 2021;14:908-915.

\section{Öz}

Amaç: İdrar yolu enfeksiyonu (IYE) çocukluk çağının önemli enfeksiyon hastalıklarından birisidir. Bazı çocuklarda renal skar gelişimine neden olarak uzun dönemde ciddi komplikasyonlara neden olmaktadır. Bu çalışmada akut piyelonefrit kliniği ile başvuran çocuk hastalarda renal hasar gelişimindeki risk faktörlerinin belirlenmesi amaçlanmıştır.

Gereç ve yöntem: Çalışmamızda Pamukkale Üniversitesi Tıp Fakültesi çocuk nefroloji polikliniğine başvuran idrar yolu enfeksiyonu tanısı ile takipli hastaların dosyaları retrospektif olarak değerlendirildi. Akut piyelonefrit tanısı idrar kültürü ve klinik bulgular ile kanıtlanmış ve Dimerkaptosuksinik asit renal sintigrafisi (DMSA) çekilmiş 197 hasta çalışmaya dahil edildi. Hastaların başvuru sırasında saptanan ve anamnezden elde edilen klinik (ateş, tekrarlayan IYE, işeme disfonksiyonu vb.), laboratuar (C-reaktif protein (CRP) ve eritrosit sedimentasyon hızı (ESH), beyaz küre sayısı (BK), polimorfonükleer lökosit sayısı (PNL), ortalama platalet hacmi (MPV), trombosit sayıSı, serum üre ve kreatinin düzeyleri) ve görüntüleme (üriner sistem ultrasonografi (USG), voiding sistoüretrografi (VSUG) ve DMSA sintigrafisi) bulguları incelendi.

Bulgular: Kız hastaların sayısı (n:153) erkek hastaların sayısından (n:44) anlamlı olarak daha yüksek saptandı $(p<0,001)$. Hastaların tedavi öncesi ateş düzeyinin $38^{\circ} \mathrm{C}$ ve üzerinde olması, klinik bulguların iki gün ve daha fazla süredir devam ediyor olması, tekrarlayan IYE varlığı, BK, PNL, ESH ve CRP yüksekliğinin renal hasarlanmayı artırdığı tespit edildi $(p<0,001)$. USG ve VSUG' nin renal hasarlanmayı gösterme açısından düşük sensitiviteye sahip olduğu görüldü.

Selcuk Yuksel, Prof. Pamukkale University Faculty of Medicine, Department of Pediatrics, Department of Pediatric Rheumatology and Pediatric Nephrology, Kinikli Campus, Denizli, Turkey, e-mail: selcukyuksel.nephrology@gmail.com (https://orcid.org/0000-0001-9415-1640)

Tulay Becerir, Ass. Prof. Pamukkale University Faculty of Medicine, Department of Pediatrics, Department Pediatric Nephrology, Kinikli Campus, Denizli, Turkey, e-mail: tulaybecerir@gmail.com (https://orcid.org/0000- 0001-6277-1458) (Corresponding Author)

Burcin Seyhan, MD. Denizli State Hospital, Department of Pediatrics, Denizli, Turkey, e-mail: drburcinkaya@yahoo.com (https://orcid.org/00000001-9177-7461) 
Sonuç: Hastaların başvuru sırasında tespit edilen klinik ve laboratuar verileri ile renal hasarlanma oranı belirlenmesi bu hastalarda uygun takip ve tedavi ile morbidite ve mortalite oranının azaltılmasını sağlayabilir.

Anahtar kelimeler: İdrar yolu enfeksiyonu, çocuk, risk faktörleri, renal skar, ateş.

Yüksel S, Becerir T, Seyhan B. İdrar yolu enfeksiyonu geçiren çocuk hastalarda klinik ve laboratuvar kanıtların böbrek hasarı ile ilişkisinin değerlendirilmesi. Pam Tıp Derg 2021;14:908-915.

\section{Introduction}

Urinary tract infection (UTI) is one of the important infectious diseases of childhood age $[1,2]$. Although, the frequency varies depending on age and gender, particularly upper urinary tract infections are known to cause serious renal damage and late-term serious morbidity [1-5]. Urinary tract infection is defined as the infections due to localization and growth of most common bacteria and rarely viruses and fungi in any site of the urinary tract system [1, 2]. The infection of renal parenchyma and collecting system is considered as acute pyelonephritis while cystitis and urethritis are the terms indicating the infections of lower urinary tract system [1].

It has been reported that renal damage develops in $10-64 \%$ of the pediatric patients with acute pyelonephritis [1]. The factors responsible for development of renal damage in UTI are not yet clear. The development of renal damage may cause hypertension in the late term as well as it may manifest a clinical course progressing to gestational complications and chronic kidney failure $[1,5]$.

At the present time, renal cortical scintigraphy is the best technique that reveals the renal damage due to acute pyelonephritis $[6,8]$. It has been reported that renal damage encountered by scintigraphic techniques performed during or a while after acute pyelonephritis is closely related with clinical and laboratory evidence detected at the beginning of the disease. Low age, high levels of C-reactive protein (CRP) and erythrocyte sedimentation rate (ESR), the presence of vesicoureteral reflux (VUR), high fever, delayed treatment and the presence of recurrent pyelonephritis are the risk factors suggested for development of renal parenchymal damage [8-19].

In the present study, it was aimed to investigate the risk factors in development of renal scarring in the patients that applied with clinical evidence of acute pyelonephritis and to compare the sensitivity of dimercaptosuccinic acid (DMSA) renal scintigraphy marked with Tc99m to ultrasonography and voiding cystourethrography (VCUG) in determination of renal damage.

\section{Materials and methods}

Data of the patients that admitted to pediatric nephrology polyclinic of Pamukkale University and that were diagnosed with urinary tract infection were retrospectively evaluated based on polyclinic patient files. The medical files of totally 480 patients followed-up with diagnosis of UTI were evaluated. The patients in whom diagnosis of urinary tract infection was not confirmed by urine culture, DMSA scintigraphy was not performed and the patients with an additional anomaly (major urogenital system anomaly, anorectal malformation, neurological and obstructive urological anomaly) were excluded from the study.

The study was approved by "Ethics Committee of Pamukkale University" of the hospital before the start of the study.

High fever $\left(\geq 38^{\circ} \mathrm{C}\right)$ detected by anamnesis and during examination, vomiting, restlessness, malnutrition and abdominal distention in the young pediatric patients, abdominal pain, side pain and costovertebral angle tenderness in the older pediatric patients were considered as the clinical evidence of acute pyelonephritis. The recurrent UTI, constipation and voiding dysfunction were questioned.

The definition of infection was based on the presence of pyuria alone or accompanied by hematuria, nitrite positivity and growth of $\geq 100,000$ colonies $/ \mathrm{ml}$ from one bacterium in the urine culture samples obtained by attaching urine drainage bag and transurethral catheter techniques in the young pediatric patients and midstream urine samples in the older pediatric patients. In addition to these findings, CRP positivity by immunoturbidimetric method $(>0.5$ $\mathrm{mg} / \mathrm{L}$ ), ESR value greater than $20 \mathrm{~mm} /$ hour by Westergren method and white blood cell count $>10,000 \mathrm{~K} / \mu \mathrm{L}$ in complete blood count test (by 
Cell-Dyn 3700 device) were evaluated as the evidence of acute pyelonephritis.

Anthropometric data, clinical evidence, fever duration, voiding dysfunction, constipation, recurrent UTI, laboratory evidence, CRP, ESR, white blood cell (WBC) count, polymorphonuclear leukocyte (PNL) count, mean platelet volume (MPV), platelet count, serum urea, serum creatinine, proteinuria, leukocytouria, the presence of nitrite, erythrocytouria, urine culture, the findings of urinary system USG, VCUG and DMSA of all the patients were recorded.

VUR grading was performed according to the recommendation of International Reflux Study Committee (37). In the study, the patients with Grade 1 and 2 VUR, Grade 3 VUR and those with Grade VUR 4 and 5 according to VCUG results were grouped as mild, moderate and severe patients, respectively.

\section{Statistical analysis}

Statistical analysis of the study data was performed using SPSS Version 10.0 (Statistical Package for Social Sciences) software package. Frequency table was used for the descriptive statistics while paired quantitative values were compared by t-test, ANOVA test was performed for comparison between triple quantitative values and qualitative data was compared by carrying out Chi-Square analysis.

\section{Results}

The study included 197 patients. Of those, $44(22.3 \%)$ were male and $153(77.7 \%)$ were female. The ages of the pediatric patients ranged between 1 month and 16 years (mean 4.7 4 4.05 years). Mean age of the male patients was lower than that of female patients $(4.7 \pm 4$ years vs $5.45 \pm 3.9$ years, respectively) $(p<0.001)$.

Urine cultures revealed growth of E. coli, Klebsiella pneumoniae, Enterobacter spp, Pseudomonas spp, Proteus mirabilis and other bacteria (Morganella morganii, Serratia spp, Citrobacter spp, Candida spp) with rates of $79.2 \%, 8.6 \%, 5.6 \%, 2.5 \%, 2 \%$ and $2 \%$, respectively.

It was determined that DMSA scintigraphy was performed on average $47 \pm 13$ days (7-100 days) after treatment of acute pyelonephritis. DMSA results were normal in 53.8\% $(n=106)$ of those patients whereas acute changes and renal scarring were encountered in $37.6 \%$ $(n=74)$ and $8.6 \%(n=17)$ patients, respectively.

The evaluation of DMSA results in terms of age groups showed abnormal scintigraphic findings in $35 \%, 56.7 \%$ and $42 \%$ of $0-1,1-5$ and $5 \leq$ age group patients, respectively. No statistically significant difference was found between the age groups regarding the frequency of abnormal scintigraphic findings $(p=0.053)$ (Figure 1).

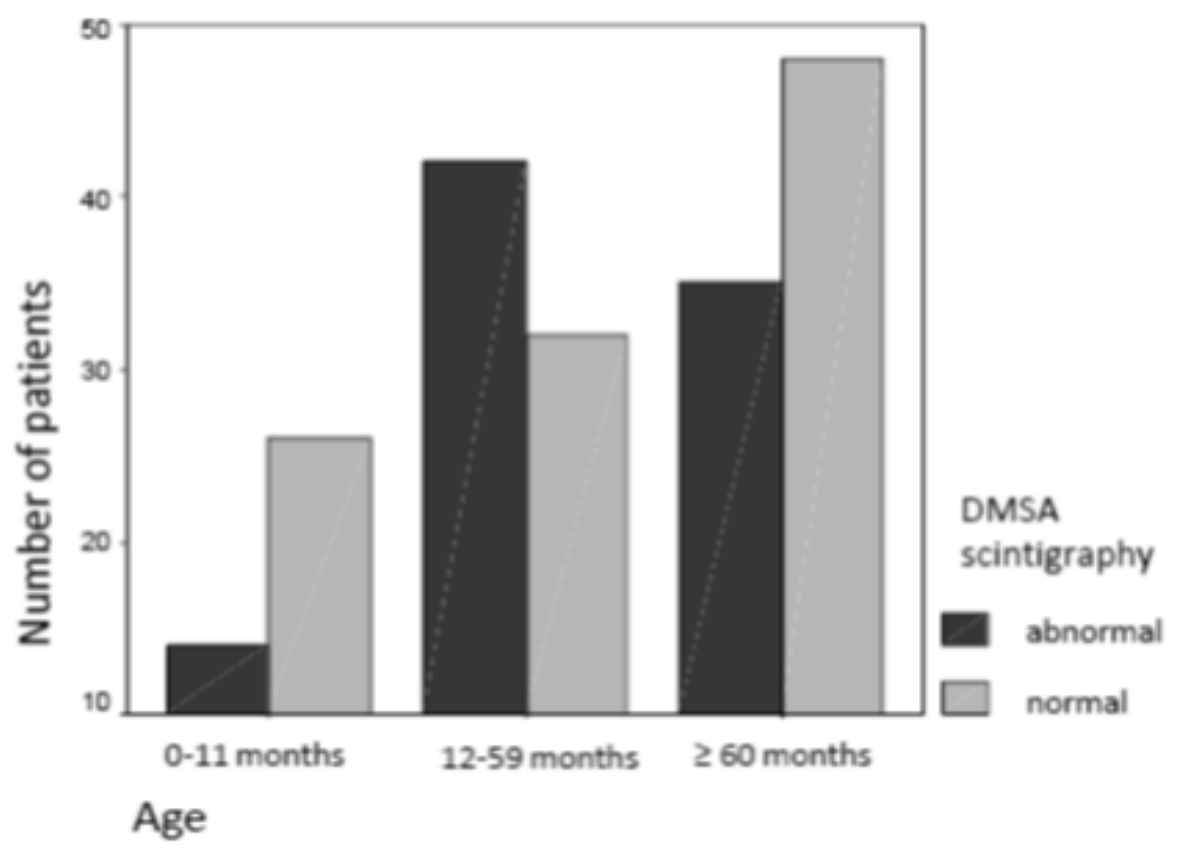

Figure 1. Distribution of DMSA scintigraphy findings by age groups DMSA: Dimercaptosuccinic acid 
It was found that body temperature of $38^{\circ} \mathrm{C}$ and above detected during clinical course of acute pyelonephritis, persisting clinical evidence for 2 days or longer and the presence of recurrent UTI history significantly increased the probability of abnormal scintigraphic findings $(p<0.001)$. DMSA scintigraphy results showed no significant correlation with voiding dysfunction and the presence of constipation $(p>0.05)$ (Table 1). It was encountered that elevated white blood cell count, polymorphonuclear leukocyte count, CRP and ESR increased risk for development of renal damage $(p<0.001)$ (Table 2$)$.

Table 1. Relationship between clinical findings and scintigraphic changes

\begin{tabular}{|c|c|c|c|c|}
\hline & $\begin{array}{l}\text { DMSA scintigraphy } \\
\text { Normal }\end{array}$ & $\begin{array}{l}\text { DMSA scintigraphy } \\
\text { Abnormal }\end{array}$ & Total & $p$ \\
\hline \multicolumn{5}{|l|}{ Fever } \\
\hline$<37^{\circ}(\mathrm{n}, \%)$ & $65(73.9)$ & $23(26.1)$ & $88(100)$ & \\
\hline $37^{0}-38^{0}(n, \%)$ & $19(48.7)$ & $20(51.3)$ & $39(100)$ & $<0.001$ \\
\hline$>38^{\circ}(n, \%)$ & $22(31.4)$ & $48(68.6)$ & $70(100)$ & \\
\hline Total $(\mathrm{n}, \%)$ & $106(53.8)$ & $91(46.2)$ & $197(100)$ & \\
\hline \multicolumn{5}{|l|}{ Duration of fever } \\
\hline less than 2 days $(n, \%)$ & $100(63.7)$ & $57(36.3)$ & $157(100)$ & \\
\hline 2 days or longer $(n, \%)$ & $6(15)$ & $34(85)$ & $40(100)$ & $<0.001$ \\
\hline Total $(n, \%)$ & $106(53.8)$ & $91(46.2)$ & $197(100)$ & \\
\hline \multicolumn{5}{|l|}{ Voiding dysfunction } \\
\hline Yes (n, \%) & $27(46.6)$ & $31(53.4)$ & $58(100)$ & \\
\hline No $(n, \%)$ & $40(61.5)$ & $25(38.5)$ & $65(100)$ & $>0.05$ \\
\hline Total $(n, \%)$ & $67(54.5)$ & $56(45.5)$ & $123(100)$ & \\
\hline \multicolumn{5}{|l|}{ Recurrent UTI } \\
\hline Yes (n, \%) & $28(32.6)$ & $58(67.4)$ & $86(100)$ & \\
\hline No $(n, \%)$ & $78(70.3)$ & $33(29.7)$ & $111(100)$ & $<0.001$ \\
\hline Total (n, \%) & $106(53.8)$ & $91(46.2)$ & $197(100)$ & \\
\hline \multicolumn{5}{|l|}{ Constipation } \\
\hline Yes (n, \%) & $16(53.3)$ & $14(46.7)$ & $30(100)$ & \\
\hline No $(n, \%)$ & $90(53.9)$ & $77(46.1)$ & $167(100)$ & $>0.05$ \\
\hline Total (n, \%) & $106(53.8)$ & $91(46.2)$ & $197(100)$ & \\
\hline
\end{tabular}

DMSA; Dimercaptosuccinic acid

Table 2. Relationship between laboratory data and scintigraphic findings

\begin{tabular}{llll}
\hline & DMSA Normal & DMSA Abnormal & $p$ \\
\hline Urea $(\mathrm{mg} / \mathrm{dl})$ & $20.6 \pm 7.5$ & $22.4 \pm 8.3$ & $>0.05$ \\
Creatinine $(\mathrm{mg} / \mathrm{dl})$ & $0.40 \pm 0.11$ & $0.44 \pm 0.15$ & $<.087$ \\
PNL $(\%)$ & $55.7 \pm 9.4$ & $62 \pm 10.1$ & $<0.001$ \\
Platelet $(\mathrm{K} / \mu \mathrm{L})$ & $335179.2 \pm 91070.4$ & $341714.3 \pm 107141.9$ & $>0.05$ \\
ESH $(\mathrm{mm} / \mathrm{saat})$ & $20 \pm 16.4$ & $13723.4 \pm 4952.9$ & $<0.001$ \\
White Blood cell $(\mathrm{K} / \mu \mathrm{L})$ & $11104.7 \pm 4547.1$ & $3.63 \pm 5.6$ & $<0.001$ \\
CRP $(\mathrm{mg} / \mathrm{L})$ & $1.40 \pm 3.5$ & $=0.001$ & \\
\hline
\end{tabular}

PNL: polymorphonuclear leukocytes, ESR: Erythrocyte sedimentation rate, CRP: C-reactive protein 
Only $19.3 \%$ of the patients had abnormal urinary system findings in USG. Also DMSA scintigraphy encountered pathology in $84.2 \%$ of the patients with abnormal USG findings whereas $15.8 \%$ of those patients had normal DMSA scintigraphy results. If scintigraphic evidence is accepted as gold standard according to these results; sensitivity, specificity, positive predictive value and negative predictive value of USG in predicting acute pyelonephritis findings were $35.2 \%, 94.3 \%, 84.2 \%$ and $62.9 \%$, respectively $62.9 \%$ (Table 3).
Voiding cystourethrography was performed in 174 patients. No VUR was detected in 142 (72.1\%) patients, Grade 1-2 VUR, Grade 3 VUR and Grade 4-5 VUR were identified in $16(8.1 \%), 13(6.6 \%)$ and $3(1.5 \%)$ patients, respectively. DMSA scintigraphy also revealed pathology in $65.6 \%$ of the patients detected with VUR. If scintigraphic evidence is accepted as gold standard; sensitivity, specificity, positive predictive value and negative predictive value of VCUG in identifying pathology were found $25.6 \%, 88 \%, 65.6 \%$ and $57 \%$, respectively (Table 3).

Table 3. Comparison of ultrasonography, voiding cystourethrography and DMSA scintigraphy findings

\begin{tabular}{llll}
\hline & Sensitivity (\%) & Specificity (\%) & Pozitive predictive value (\%) \\
\hline USG & 35.2 & 94.3 & 84.2 \\
VCUG & 25.6 & 88 & 65.6 \\
\hline
\end{tabular}

USG: Ultrasonography, VSUG: voiding cystourethrography

\section{Discussion}

It has been found in the present retrospective study that fever degree, fever duration, the presence of recurrent UTI, increased white blood cell count and elevated levels of ESR and CRP increased the risk of renal damage. DMSA scintigraphy results of the patients indicated that approximately half of the patients had renal damage and that renal damage predominantly involved acute changes.

There are studies in the literature that showed the relationship between development of renal scarring and fever degree in the patients who admitted with acute pyelonephritis. Pecile et al. [10] have found in their study on 316 pediatric patients that the detection rate of abnormal finding in DMSA scintigraphy was $17 \%$ in the patients with pretreatment maximum body temperature $<38^{\circ} \mathrm{C}$ whereas that rate was $74 \%$ in the patients with body temperature $>39^{\circ} \mathrm{C}$. Similarly, it was also determined in our study that the presence of high fever degree increased the risk for renal damage and that this correlation was statistically significant. In addition, delayed fever duration or delayed treatment onset for pyelonephritis has been also reported as a risk factor for development of renal scarring [11]. Also we have determined that DMSA scintigraphy was affected by $85 \%$ in the pediatric patients with finding of high fever for 2 days or longer in our study. However, it has been suggested in the recent times that delayed treatment onset is not a risk factor for development of renal scarring and that once occurrence of parenchymal affection at the beginning of infection will result in renal damage [12]. This theory has been supported by two separate studies that evaluated 213 and 287 pediatric patients. It has been emphasized according to these two studies that preventing development of acute pyelonephritis is essentially more critical as well as treating acute pyelonephritis [12, 13, 20].

Yuksel et al. [9] have reported that the detection rate of abnormal scintigraphy finding was $62 \%$ when the time of performing scintigraphy was limited by the first 7 days after onset of pyelonephritis whereas the detection rate of abnormal scintigraphy finding decreased to $49 \%$ when the time of performing scintigraphy was limited by 30 days. We obtained similar results with this study. In pediatric patients with acute pyelonephritis, the detection rate of abnormal scintigraphy findings decreases as the time interval between the onset of the disease and the time of scintigraphy increases. This result supports the conclusion that risk for development of renal scarring can be reduced by treatment.

It is accepted that patient age is an important risk factor for development of renal scarring after acute pyelonephritis and that risk increases as 
the patient age decreases. It has been reported that infants (below one year of age) carry the highest risk while the pediatric patients aged over 5 years carry lower risk [21, 22]. On the contrary, some studies have reported that age is positively correlated with the development of renal scarring [9, 10]. Yuksel et al. [9] have carried out a study on 201 patients with acute pyelonephritis aged between 0-14 years and identified abnormal scintigraphy findings with the rates of $22 \%, 47 \%$ and $53 \%$ in the pediatric patients aged below one-year-old, between 1-5 years and over 5 years, respectively. Also in our study, the rates of renal damage were $35 \%, 56.7 \%$ and $42 \%$ in the pediatric patients aged below one-year-old, between 1-5 years and over 5 years, respectively. Even though, the detection rate of abnormal scintigraphy finding was found higher than the other groups, however, no statistically significant difference was found between the age groups regarding detection rate of abnormal scintigraphic finding.

It has been demonstrated that irreversible renal damage occurs due to inflammation, interstitial injury and fibrosis that develop during acute pyelonephritis. This state is defined as the development of renal scarring displayed with renal scintigraphic examination. In addition, some authors have shown that inflammatory process continues even after recovery of urinary tract infection [23, 24]. Febrile recurrent UTI has been identified to be an independent risk factor for renal scarring in a prospective study conducted on 565 pediatric patients with febrile UTI and/or VUR. It has been observed in the same study that DMSA scintigraphy findings were normal during follow-up process in $76 \%$ of the patients despite recurrent febrile UTI episodes [25]. In also our study, normal scintigraphic findings were monitored in $32.6 \%$ of the patients with recurrent urinary tract infection. Although, no reason for nonoccurrence of renal scarring despite recurrent UTIs in some pediatric patients, it has been suggested that genetically protective factors may be present. It is considered that immune response of the host has a critical role in development of renal scarring [20]. DMSA is gold standard in the diagnosis of acute pyelonephritis. However, scintigraphy is most commonly not performed during diagnosis since it is an invasive procedure. The fact that some patients followed-up with diagnosis of pyelonephritis may not be a true case of pyelonephritis may also affect these results.

High white blood cell count and increased levels of CRP and ESR are the important laboratory parameters. Several studies have reported that there is a positive correlation between development of renal damage and high white blood cell account. Doganis et al. [12] have ascertained in their study on 278 patients that mean white blood cell count was significantly higher in the patients with abnormal scintigraphic findings. Similar results were obtained also in our study. However, there are also some studies that demonstrated that there is no relationship between white blood cell count and renal damage [26, 27]. In our study, mean CRP level was found significantly higher in the patients with abnormal scintigraphic findings compared to those with normal scintigraphic findings. CRP is one of the most important laboratory parameters in differentiation between upper and lower urinary tract infections. Therefore, many studies have addressed the relationship between CRP and renal damage. The studies have shown that the patients with abnormal findings in DMSA scintigraphy after acute pyelonephritis had significantly higher CRP levels. In contrast to other studies, Jakobsson et al. [8] have found no difference between CRP levels of the patients detected and not detected with renal scarring in DMSA scintigraphy. ESR is also one of the distinctive criteria like CRP in diagnosis of acute pyelonephritis. Garin et al. [16] have reported that ESR has higher sensitivity than CRP in diagnosis of acute pyelonephritis. The studies have shown that ESR values of the patients with renal damage than those without renal damage $[9,12,16]$. Similarly, with the studies in the literature, mean ESR values of the group with abnormal scintigraphy findings were found statistically higher than that of the group with normal scintigraphy findings in also our study.

Even though, ultrasonography does not provide adequate information about renal functions, it is still the primarily performed imaging method in diagnosis of the pediatric patients. There are studies in the literature that shows the efficacy of ultrasonography in detection of renal damage [5, 6, 28]. Christian et al. [28] have carried out a study on 990 patients and obtained 
a low sensitivity rate of ultrasonography such as $21.7 \%$ in detection of renal cortical scarrings. Moorthy et al. [29] have determined a sensitivity rate of $47.2 \%$ and a specificity rate of $91.8 \%$ for ultrasonography regarding detection of diffuse renal scarring. Yuksel et al. [9] have carried out a study on 201 patients with urinary system infections and the sensitivity and specificity rates of ultrasonography in detection of renal cortical scarrings were found $29 \%$ and $90 \%$ in this study, respectively. Compared with the results of DMSA scintigraphy scan accepted as the gold standard; our results demonstrated that ultrasonography has low sensitivity although it has a high specificity in detection of renal scarring. Currently, we have concluded that ultrasonography cannot be replaced with DMSA scintigraphy.

The relationship between UTI, VUR and development of renal damage has been demonstrated in many studies. The prevalence of VUR has been reported to be approximately $30 \%$ in the pediatric patients who had febrile UTI for the first time. However, the frequency of VUR in the healthy population is not known [1]. The present study showed that VUR was detected in $18.4 \%$ of the patients that had pyelonephritis. That rate was reported to be $22 \%$ by Yuksel et al. [9]. In our study, sensitivity, specificity, positive predictive value and negative predictive value of VCUG in identifying pathology were found $25.6 \%, 88 \%, 65.6 \%$ and $57 \%$, respectively. In the study of Moorthy et al. [4], senstivity and specificity rates of VCUG regarding detection of diffuse renal scarring to be $50 \%$ and $89.9 \%$, respectively. Yuksel et al. [9] have reported the sensitivity and specificity rates of VUCG in detection of renal cortical scarrings to be $33 \%$ and $94 \%$, respectively.

In conclusion, urinary tract infection is an important infectious disease that should be considered seriously and treated meticulously. The rate of renal damage can be determined by the clinical and laboratory data obtained at baseline admission of the patients. Taking lateterm serious complications into consideration, morbidity and mortality rates can be reduced by appropriate management and treatment

Conflict of interest: No conflict of interest was declared by the authors.

\section{References}

1. Tullus $\mathrm{K}$, Shaikh $\mathrm{N}$. Urinary tract infections in children. Lancet 2020;395:1659-1668. https://doi.org/10.1016/ S0140-6736(20)30676-0

2. Millner R, Becknell B. Urinary tract infections. Pediatr Clin North Am 2019;66:1-13. https://doi.org/10.1016/j. pcl.2018.08.002

3. Foxman B. Epidemiology of urinary tract infections: incidence, morbidity, and economic costs. Am J Med 2002;113;5-13. https://doi.org/10.1016/s00029343(02)01054-9

4. Moorthy I, Easty M, McHung K, Ridout D, Biassoni D, Gordon I. The presence of vesicoureteric reflux does not identify a population at risk for renal scarring following a first urinary tract infection. Arch Dis Child 2005;90:733736. https://doi.org/10.1136/adc.2004.057604

5. Yüksel S, Yüksel G, Çakar N. Urinary tract infection in children. T Klin Pediatri 2002;11:41-49.

6. Sinha MD, Gibson P, Kane T, Lewis MA. Accuracy of ultrasonic detection of renal scarring in different centres using DMSA as the gold standart. Nephrol Dial Transplant 2007;22:2213-2216. https://doi. org/10.1093/ndt/gfm155

7. Benador D, Benador N, Slosman D, Mermillod B, Girardin E. Are younger children at highest risk of renal sequelae after pyelonephritis? Lancet 1997;349:17-19. https://doi.org/10.1016/S0140-6736(96)06126-0

8. Jakobsson B, Berg U, Svensson L. Renal scarring after acute pyelonephritis. Arch Dis Child 1994;70:111-115. https://doi.org/10.1136/adc.70.2.111

9. Yüksel $S$, Çakar N, Çakmak FN, et al. Risk factors of renal damage in children with acut pyelonephritis. Turkiye Klinikleri J Pediatr 2007;16:158-164.

10. Pecile P, Miorin E, Romanello C, et al. Age-related renal paranchymal lesions in children with first febrile urinary tract infections. Pediatrics 2009;124:23-29. https://doi.org/10.1542/peds.2008-1192

11. Hiraoka M, Hashimoto G, Tsuchida S, Tsukahara $\mathrm{H}$, Ohshima $\mathrm{Y}$, Mayumi M. Early treatment of urinary infection prevents renal damage on cortical scintigraphy. Pediatr Nephrol 2003;18:115-118. https:// doi.org/10.1007/s00467-002-1023-y

12. Doganis D, Siafas K, Mavrikou M, et al. Does early treatment of urinary tract infection prevent renal damage? Pediatrics 2007;120:922-928. https://doi. org/10.1542/peds.2006-2417

13. Hewitt IK, Zucchetta P, Rigon L, et al. Early treatment of acute pyelonephritis in children fails to reduce renal scarring: data from the Italian renal Infection study trials. Pediatrics 2008;122:486-490. https://doi. org/10.1542/peds.2007-2894

14. Smellie JM, Poulton A, Prescod NP. Retrospective study of children with renal scarring associated with reflux and urinary infection. BMJ 1994;308:1193-1196. https://doi.org/10.1136/bmj.308.6938.1193 
15. Chang SL, Shortliffe LD. Pediatric urinary tract infections. Pediatr Clin North Am 2006;53:379-400. https://doi.org/10.1016/j.pcl.2006.02.011

16. Garin EH, Olovarria F, Araya C, Broussain M, Barrea $C$, Young L. Diagnostic significance of clinical and laboratory findings to localize site of urinary infection. Pediatr Nephrol 2007;22:1002-1006. https://doi. org/10.1007/s00467-007-0465-7

17. Lai SW, Ng KC. Retrospective analysis of inflammatory parameters in acute pyelonephritis. Scand J Urol Nephrol 2003;37:250-252. https://doi. org/10.1080/00365590310008145

18. Soylu A, Kasap B, Demir K, Türkmen M, Kavukçu S. Predictive value of clinical and laboratory variables for vesicoureteral reflux in children. Pediatr Nephrol 2007;22:844-848. https://doi.org/10.1007/s00467-0060418-6

19. Oostenbrink R, Van der Heijden AJ, Moons KG, Moll HA. Prediction of vesico-ureteric reflux in childhood urinary tract infection: a multivariate approach. Acta Paediatr 2000;89:806-810.

20. Kosmeri C, Kalaitzidis R, Siomou E. An update on renal scarring after urinary tract infection in children: what are the risk factors? J Pediatr Urol 2019;15:598-603. https://doi.org/10.1016/j.jpurol.2019.09.010

21. Spencer JR, Schaeffer AJ. Paediatric urinary tract infections. Urol Clin North Am 1986;13:661-672.

22. Gleeson FV, Gordon I. Imaging in urinary tract infection. Arch Dis Child 1991;66:1282-1283.

23. Kaack MB, Dowling KJ, Patterson GM, Roberts JA. Immunology of pyelonephritis VIII. E. coli causes granulocytic aggregation and renal ischemia. J Urol 1986;136:1117-1122. https://doi.org/10.1016/s00225347(17)45235-9

24. Roberts JA. Mechanisms of renal damage in chronic pyelonephritis (reflux nephropathy). Curr Top Pathol 1995;88:265-287. https://doi.org/10.1007/978-3-64279517-6_9

25. Snodgrass WT, Shah A, Yang M, et al. Prevalence and risk factors for renal scars in children with febrile UTI and/or VUR: a cross-sectional observational study of 565 consecutive patients. J Pediatr Urol 2013;9:856863. https://doi.org/10.1016/j.jpurol.2012.11.019

26. Ferreiro C, Piepsz A, Nogarède C, Tondeur M, Hainaut $M$, Levy J. Late renal sequelae in intravenously treated complicated urinary tract infection. Eur J Pediatr 2013;172:1243-1248. https://doi.org/10.1007/s00431013-2024-5

27. Keren $\mathrm{R}$, Shaikh $\mathrm{N}$, Pohl $\mathrm{H}$, et al. Risk factors for recurrent urinary tract infection and renal scarring. Pediatrics 2015;136:13-21. https://doi.org/10.1542/ peds.2015-0409
28. Christian MT, McColl JH, MacKenzie JR, Beattie TJ. Risk assesment of renal cortical scarring with urinary tract infection by clinical features and ultrasonography. Arch Dis Child 2000;82:376-380. https://doi. org/10.1136/adc.82.5.376

29. Moorthy I, Wheat D, Gordon I. Ultrasonography in the evaluation of renal scarring using DMSA scan as the gold standard. Pediatr Nephrol 2004;19:153-156. https://doi.org/10.1007/s00467-003-1363-2

Ethics committee approval: The study was approved by the ethic committee of Pamukkale University (date: 14.01.2011 and number: B.30.2.PAÜ.0.20.05.09/11).

\section{Authors' contributions}

S.Y. built the main idea and hypothesis. B.S. arranged the material and method section and evaluated the data. The article was written, reviewed and necessary corrections were made by T.B. and S.Y. In addition, all authors discussed the entire study and approved the final version. 